This is an electronic reprint of the original article. This reprint may differ from the original in pagination and typographic detail.

Author(s): Chou, Yueh-Ching; Kröger, Teppo

Title: $\quad$ Reconciliation of work and care among lone mothers of adults with intellectual disabilities: the role and limits of care capital

Year: $\quad 2014$

Version:

Please cite the original version:

Chou, Y.-C., \& Kröger, T. (2014). Reconciliation of work and care among lone mothers of adults with intellectual disabilities: the role and limits of care capital. Health and Social Care in the Community, 22(4), 439-448. https://doi.org/10.1111/hsc.12100

All material supplied via JYX is protected by copyright and other intellectual property rights, and duplication or sale of all or part of any of the repository collections is not permitted, except that material may be duplicated by you for your research use or educational purposes in electronic or print form. You must obtain permission for any other use. Electronic or print copies may not be offered, whether for sale or otherwise to anyone who is not an authorised user. 


\title{
Reconciliation of work and care among lone mothers of adults with intellectual disabilities: the role and limits of care capital
}

\begin{abstract}
In this study the concept of social capital is applied to an exploration of Guanxi

(social networking to create good relationships) among working lone mothers of adults with intellectual disabilities (ID) in Taiwan. Using in-depth interviews, this study explores the role of social capital, here referred to as 'care capital', in making it possible for working lone mothers to combine their roles as family carers and workers.
\end{abstract} Eleven divorced or widowed mothers combining their paid work with long-term care responsibilities were recruited from a survey or through NGOs and were interviewed at their home between October 2008 and July 2010. An interpretative phenomenological approach was adopted for data analysis. The findings revealed that the mothers' care capital was extremely limited and was lost, gained, and lost again during their life cycles of long-term caregiving. Guanxi, especially in relation to their employers, proved to be the sole source of care capital for these mothers, making reconciliation between work and care responsibilities possible. In the absence of formal or informal support, religion and the mother-child relationship seemed also to become a kind of care capital for these lone mothers, helping them to get by with their lifelong care responsibilities. For formal social and health care services, not just in Taiwan but in every country, it is important to develop support for lone mothers of 
adults with ID who have long-term care responsibilities and low levels of care capital and thus face care poverty.

Keywords: lone mother, intellectual disability, work and care, social capital, care capital, care poverty 
What is known about the topic

- Mothers of adults with intellectual disabilities are known to face difficult challenges as family carers.

- The concept of social capital has been used to explore work-family conflicts of families with children.

- In Chinese context, social capital has been linked with the concept of Guanxi (good relationships).

What this study adds to literature

- It addresses the gap in research on work-care reconciliation among lone mothers of adults with ID.

- These mothers were found to have very limited access to 'care capital', which was lost, gained and lost again over the life cycle.

- Guanxi with employers proved to be the sole resource to make paid work possible for lone mothers. 


\section{Introduction}

The conceptual framework of social capital has been widely used to explore conflicts between work and family among lone mothers and other mothers with young children (Stoloff et al. 1999, Ciabattari 2007, Millar \& Ridge 2008). In terms of family carers, social capital has been understood to refer to care-related social relationships at the individual level (Lin 2001, Brisson \& Usher 2007). Difficulties encountered by mothers who try to balance paid work and childcare have been addressed in many Western studies (Crouter 1984, Biernat \& Wortman 1991, Beaujot \& Liu 2005) and Asian studies (Aryee et al. 1999, Lu et al. 2006, Spector et al. 2007); however most of these studies have only focused on mothers of young children without disabilities. It has been rare for studies to analyse how mothers of disabled children reconcile their paid work and long-term care responsibilities. It is even rarer to use the framework of social capital in such an analysis.

This paper aims to use the approach of social capital to analyse the reconciliation between work and family for Taiwanese lone mothers of an adult child with intellectual disabilities (ID). This group of mothers faces extreme challenges in combining paid work and caregiving and thus knowledge on their situation is relevant for understanding work-family reconciliation also among other carer groups and in different national contexts. In Taiwan caring of family members with disabilities is still viewed mostly as a family responsibility and the primary carers are usually mothers. In 2012, 99,621 people of Taiwan’s population of 23 million were diagnosed with ID; $93 \%$ of these people lived with their families and more than $80 \%$ of these people were adults (MOI, Taiwan 2009). Families with children with ID not only have the long-term responsibility and stress of caring but also need to cope with a feeling of being devalued by society (Chou \& Palley 1998). Public services are not 
firmly institutionalised in Taiwan and employers are not expected to be involved in supporting family caregiving of their employees (Chou et al. 2013). In such a context, for lone mothers of adults with ID to combine paid work and caregiving is on the one hand very complicated, but on the other hand vital, as it is the most secure way to meet the financial needs of their families. The paper studies whether, in order to be able to reconcile working and caring, these mothers build up Guanxi (關係), 'good relationships by social networking', which is a traditional way of interaction in societies influenced by Chinese culture (Chan et al. 2010). Guanxi is understood here as social capital that needs to be created and accumulated in order for lone mothers to be able to combine their two roles of caregiving and paid work. It is analysed here as 'care capital', that is, social capital that functions as a resource when lone mothers are building up care arrangements for their children (Kröger 2003, 2010).

\section{Social capital, Guanxi and care capital}

Social capital can be used in relation to an individual's connections with social networks (Coleman 1988, Lin 2001). Coleman (1994) defined social capital functionally, that is, social capital can be generated by networks of relationships, reciprocity, trust, and social norms. These can be created and therefore they will influence an individual's well-being. For example, when social capital is applied to the network involving employment, an individual may gain resources or benefits from the workplace (Putnam 2000).

The most common distinction between the various forms of social capital is that between bonding and bridging social capital (Putnam 2002, Dominquez \& Watkins 2003, Brisson 2009). Often, frequent contact with relatives, friends and neighbours is 
considered to form bonding social capital (Lowndes 2004, Brisson \& Usher 2007, Derose 2008), while participation in heterogeneous groups is conceptualised to form bridging social capital (Putnam 2000). The former networks are also referred to as ‘informal capital' and the latter ones are termed 'formal capital' (Brisson 2009). Briggs (1998) writes about social capital as being used for 'getting by' versus 'getting ahead.' 'Getting by' refers to relationships that help maintain the status quo, while 'getting ahead' refers to relationships that advance an economic situation.

In a Chinese context the concept of social capital has been closely linked with the concept of Guanxi, that is, social networking to create good relationships (Xin \& Pearce 1996). Guanxi describes a personal connection, social capital, and gift between two people in which one is able to prevail upon another to perform a favour or service, or be prevailed upon to do a favour (Gold et al. 2002).

The opportunities of lone mothers to participate in paid work and avoid poverty can be expected to be largely determined by their access to social capital. Lone motherhood is closely connected to family relationships, to the culture in terms of gender issues, and to the type of welfare regime prevailing in the country; in addition, lone mothers' conditions are also related to the structures and ongoing changes in the labour market (Kamerman \& Kahn 1988, Duncan \& Edwards 1999, Skevik 2005). In the past two decades, there have been numerous studies in Western countries on how lone mothers combine employment and care responsibilities (e.g. Harris 1993, Casey \& Pitt-Catsonphes 1994, Mason 2003, Spencer-Dawe 2005, Kröger 2010). One comparative European study differentiated between informal and formal care resources, and developed the concept of 'care poverty' to characterise a situation where a lone mother could not find an appropriate care arrangement for her children due to a lack of both formal and informal care resources (Kröger 2010). Informal care 
resources are here understood as 'informal care capital' while access to formal care services is defined as 'formal care capital', both being identified as formative elements of ‘care capital’ (Kröger 2003).

\section{Lone mothers in Taiwan}

In Taiwan, overall, there are many more lone mothers than lone fathers but lone mothers find it more difficult to participate in the labour market (Pong 2005). In Taiwan, representing the Confucian welfare regime, formal welfare services are not very developed, and informal social support thus becomes the primary source of support for the population, including lone mothers (Chang et al. 1995, Hao \& Brinton 1997). However, compared with lone fathers, lone mothers are less likely to receive support from their family with respect to childcare and housework (Chang \& Pong 1996, Chang 1999, Chen 2000, Wu 2000) and lone mothers have been noticed to receive less support even within the workplace (Lin \& Cheng 2001).

Many Taiwanese parents, primarily mothers, stay at home while their children are young and then re-enter the workforce after their children have entered elementary school (Feng \& Han 2010). However, in families who have a disabled child with long-term care needs, mothers not only stay at home when their children are young (Traustadottir 1991, Leonard et al. 1992) but also have difficulties to return back to paid employment later (Porterfield 2002, Gordon et al. 2007 ).

This paper focuses on how care capital is created and utilised by individual Taiwanese lone mothers with an adult child with ID so that they can get ahead or at least get by in performing their daily dual roles of working and caring. Not having support from a spouse, what kinds of informal and formal care capital do those lone mothers have in order to combine caregiving and paid work? What role does Guanxi 
play in this picture?

\section{Methods}

\section{Design}

This study was conducted in Taiwan between October 2008 and July 2010; and its data was collected through qualitative in-depth interviews. A purposive sample of working lone mothers with an adult child with ID were invited to be interviewed about their perspectives and experiences in regard to reconciliation between paid work and caregiving.

\section{Participants}

The interviews analysed here are a part of data of a larger project (titled XX). Its participants were recruited from parental groups, day care service centres, and among the respondents of an earlier survey on health and social care issues among adults with ID and their family carers (see Chou et al. 2010). Each participant completed a semi-structured interview. In total, 31 out of 49 mothers who participated in our interviews were involved in full-time or part-time paid work, and 11 of these working mothers were divorced or widowed when their interview was conducted. These 11 working lone mothers became the participants in the current study.

In-depth interviews

An open-ended questionnaire was developed to investigate the following areas: characteristics of current and previous paid work; conditions of caregiving; how the 
mothers balanced work and care; how support from the family, friends, neighbours, colleagues and employers helped in combining work and care; and how formal services supported coping with the two roles. The mothers' and their adult children's characteristics were also collected (Table 1). The interviews were undertaken by the principal researcher of this study, and their duration ranged from 50 minutes to 120 minutes. Each interview was held on a one-to-one basis and took place in the participant's home.

The interviews were in Mandarin or Taiwanese, depending on the participants’ spoken language, and were tape-recorded and later transcribed. We mailed a copy of the typed transcripts and made a phone call to each participant to check for errors or misunderstandings. Except for making some changes to the characteristic data related to the participants and their families, the mothers agreed with the typed transcripts. Informed consent was obtained from each participant. Ethical approval for the study was obtained from the research ethics board of XX University.

\section{Data analysis}

The transcripts were analysed using interpretative phenomenological analysis (Smith et al. 2009). In order to explore these 11 working lone mothers' specific experiences of combining paid work and caregiving, the analysis focused on how their social networking and connections or Guanxi helped them combine paid work and caregiving. The transcripts were analysed by the principal researcher, who first noted significant words, phrases or paragraphs and then identified similarities/differences across different interviews; this allowed emerging themes to be pinpointed. Such preliminary themes were then compared across the interviews and predominant themes were extracted. This process was then repeated by another co-researcher to 
check the validity of the analysis and the interpretation of the participants' accounts. This resulted in a condensed list of themes, which was then grouped into closely related themes under appropriate headings. Examples of the categories developed included 'no support from father', 'rare support from family members', 'support from other children gained and lost again', etc. Then the condensed list of themes was coded with relevant headings as presented in the results section such as 'extremely limited care capital: lost, gained and lost again’ (Table 2).

\section{Findings}

The lone mothers were between 43 and 59 years of age; eight were divorced, one was separated, and two were widows. Their education level ranged from no formal education to senior high school. The age range among the mothers' adult children with ID was from 20 to 33 years, and 6 out of these 11 children were female (Table 1).

\section{INSERT TABLE 1 HERE}

From the analysis of the data, three main themes emerged: extremely limited care capital, Guanxi with employers as the sole source of care capital, and religion and mother-child relationship becoming a new kind of care capital (Table 2).

Extremely limited care capital: lost, gained and lost again The main finding from the analysis of the interview data is that working lone mothers 
have very little access to care capital of any kind: they do not have access to affordable formal care services that would be of acceptable quality, nor do they receive much support from their family or informal networks. This main finding includes four sub-findings: fathers are no source of care capital before or after divorce, care capital from parents (and ex-parents-in-law) and siblings is lost or never existed, care capital from other children is gained and lost again, and no care capital arises from personal and formal networks (Table 2).

INSERT TABLE 2 HERE

Divorce/separation was the most usual route into lone motherhood for these women, only two (Wu \& Ku) being widows. Primary reasons mentioned for divorce/separation among the nine mothers were spousal physical abuse of the mother (Fu \& Kou), spousal abuse of the child with ID (Ping), extra marital affairs of the husband (Chao \& Kou), gambling of the husband (Huang) and money issues (Chao, Kou \& Ming). Generally, these mothers did not decide to divorce hastily, without reflection, but only after having tolerated the problem for a considerable time. During marriage, their husbands had usually not been helpful in terms of either caregiving or meeting the family's financial needs, and this lack of regard continued after the divorce (Fu, Chao, Huang, Kou \& Ming).

In contrast with Western literature (e.g. Backett-Milburn et al. 2001), the majority of these mothers did not receive support from their extended families, either. Some of the mothers had received family caregiving support initially, but over time this care capital had decreased or disappeared due to the long duration of the care needs of their child with ID or to the ageing of family members.

My mother has helped me to take care of Yin (son with ID) before; now she is not young enough to 
carry Yin anymore. It would be very dangerous if my mother felt down when she was taking care of

Yin. ....me too, I am getting old. (Fu)

Furthermore, relationships with parents-in-law could be conflicted. For example, one mother (Ping) shared with us that her nuclear family had not been respected by her father-in-law. Support from (ex-)parents-in-law remained very limited for these mothers, similar to both Hong Kongnese and Taiwanese literature which indicates that divorced lone mothers often receive very little support from in-laws (Chang \& Pong 1996, Chen 2000, Tang et al. 2010).

Some mothers had at an early stage received caregiving support from their siblings, but as the years had passed by the siblings had married and moved away, and this substitute care support was therefore lost. One mother (Lia) mentioned that her sister had suggested to her that she gave up her child with ID, and when she did not follow the suggestion, her sister stopped helping her.

The mothers interviewed here had been carers for their children with ID over two decades. Several of them also had other children who did not have a disability. When growing up, these siblings became at some point support resources for their mothers and helped with the caregiving of their sibling with ID, including financial support when they became adults and started earning. However, once the siblings married or moved out, this care capital could be lost. On the other hand, it could also be regained by the arrival of a daughter-in-law. Due to the Confucian nature of Taiwanese society, adult children, especially sons and their wives, have a responsibility to look after their parents. In our study, some mothers were living with their married son at the time they were interviewed. This implies that some types of care capital can be gained, while other types may be lost.

Perhaps surprisingly, 10 out of 11 mothers in this study indicated that they did not receive any support from their informal networks. Half of the mothers stated that 
they did not receive either financial support or assistance with caregiving from their relatives. This can be explained by the low socio-economic status of the interviewed mothers: in a previous study it was observed that such mothers are less likely to access an informal care network than women with a higher socio-economic status (Chou et al. 2013, see also Leira et al. 2005). Furthermore, their divorce had diminished support received from relatives (Pong 2005, Tang et al. 2010).

Children without disabilities grow up, and their care support needs from informal and formal networks do not continue indefinitely. However, for lone mothers with a child with ID, caregiving and needs do not stop but go on throughout the child's adult life course. Such a continuous need for support becomes too much for the informal networks of many lone mothers. Even when relatives and friends would like to help with caregiving, the special and intensive care needs of adult children with ID may make this impossible in practice. These findings are in line with those of Spencer-Dawe’s study (2005), where it was stated that the factors related to accessibility of informal care networks include the location of family members, the health status of the potential carers, and the ability of potential carers to cope with the demands of the sick child. Care capital from the extended family is easily lost over time due to the long-term and intensive care needs of the adult child with ID.

Some of the lone mothers not only had to cope with financial and caregiving difficulties, but also faced rejection by their friends and relatives and/or negative attitudes to their child with ID (Chou et al. 2009).

I have this kind of child like Wun (son with ID). I prefer not to be with my friends to avoid their strange attitudes... I feel a bit ashamed... my sister-in-law also denigrates Wun... so I do not like to have deep relationships with people. (Ping)

Being a divorced lone mother and having a child with ID may bring double stigma for these women in society. As a result of negative attitudes towards their 
children, some of the mothers had cut their connections with their personal networks, thus remaining without informal care capital.

Guanxi with employers: the sole source of care capital

All these mothers had been involved in several jobs during their work history — performing outsourced work at home, babysitting, cleaning, acting as house maids, working as waitresses in restaurants, working in a factory, vending at the night market, or doing other sorts of casual work. Some of these jobs had been offered by relatives or, alternatively, they had found them via their informal and formal networks including friends/relatives or staff working at the service centres that provided care services for their child. However, the mothers could only undertake certain types of paid work, namely those that fitted in with their need to care for their family and their child. Most paid work undertaken by these lone mothers was temporary, casual, or even not registered in the labour market. Their jobs were not stable, and specifically relied on their relationship with their employer.

For lone mothers, as previous literature has indicated, support from the workplace is very important (Parker 1994, Stoloff et al. 1999, Millar \& Ridge 2008). The relationships of these interviewed lone mothers with their employers were significant and were the key reason that they were able to combine caregiving and paid work. Guanxi with employers emerged thus as a main theme from the data and included four sub-themes: kin employers, from formal to informal relationships, fluid boundaries between the workplace and caregiving and reciprocal relationships (Table 2).

Some mothers (e.g. Jen \& Lia) were working for their relatives who were more likely to understand and accept the mothers' background and conditions. Some had worked for their employers for a longer period and built a close relationship. 
We (I and my colleagues) and our employer's wife are just like sisters... Sometimes I need to have care leave because of Fang (daughter with ID) and my employer's wife is very understanding. (Lin)

Mothers who worked as cleaners, maids, home care workers or cooks did so because the working hours fitted with the timetable of their adult child. Lone mothers who worked as cleaners at the employers' homes were also able to take their child to work. Some mothers mentioned that when they were searching for paid work, they would ask employers immediately whether they would be allowed to bring their child with ID to the workplace or whether they could sometimes ask for care leave due to an emergency with their child. These mothers said that they could not have regular paid work such as from 08:00 to 17:00. As a result, the boundary between the workplace and caregiving, as well as between the work role and the care role became blurred. A similar finding was made by Halford et al. (1997) who studied lone mothers who had a sick child. However, for the lone mothers in this study, the fluid boundary between work and care was not temporary but lasted for a long time.

Those mothers who had worked as cleaners or maids at an employer's home or workplace for years had built up interdependent trust relationships with their employers.

My employer trusts me... when I told him I need to fetch Hong (son with ID) first and then come back to work after, he agreed... sometimes I take Hong to my workplace... the pay is not so good, but he has employed me for long time. I thank him. (Chao)

My boss needs me... I do all kinds of work he gives to me, such as cleaning, laundry and nursing aid (it is a Chinese Medicine clinic)... they pay me less than usual... My boss allows me to take Yi (daughter with ID) with me for work business. (Kou)

The mothers needed to have paid work and, in particular, a workplace where they could take their children. The employers needed an employee who worked hard but 
did not request high pay. In accordance with the findings from previous studies (Nelson 2000, Dominguez \& Watkins 2003), these low-income working lone mothers and their employers built up reciprocal relationships.

This cleaning work does not have good pay, but many people have no job... I am not so young any longer, so I am in no position to complain. (Jen)

Instead of complaining about low pay, unstable work and working conditions, these lone mothers were grateful to their employers. Some mothers shared with us that they did not have a high level of education and therefore they were in no position to complain about the work. It seems that these mothers had a rather high level of tolerance and satisfaction for low-paid work. As has been found in previous studies (Bowen \& Orthner 1986, Burden 1986, Chou et al. 2008), lone mothers or persons with a lower education level actually report higher job satisfaction than other types of employees.

Religion and mother-child relationships: a new type of care capital?

All in all, both formal and informal care resources available for these lone mothers are very limited: there is no access to responsive formal services nor is there much help available from the closest family or from the broader social network. This lack of both formal and informal care capital means that these mothers face care poverty; they are also getting older themselves and see their health deteriorating. Surprisingly, however, in such a situation, these mothers did not get totally discouraged or become drug or alcohol users, instead, they found strength and motivation to go forward from the mother-child relationship or from a belief in religion or fate.

Wan (daughter with ID) has been my motivation to live after my husband passed away... my other children (siblings of child with ID) are married and have moved out... Wan needs my care... Wan has become my greatest motivation for living. (Wu) 
Yin (daughter with ID) needs me, otherwise my life is already ended... I fought with my former husband. I was tied to her... I do not feel lonely because of having her... earlier I was not so strong and now I am much stronger because of her. (Lia)

Some mothers shared that while fighting with their former husband or after their husband had passed away, the child with ID was their only available companion within the family, and this motivated them to keep on living and even to become stronger. The findings here echo previous studies (Burt 1987, Wellman \& Gulia 1999), which have indicated that ties between the mother and the child with disabilities offered leverage that allowed the mothers to improve their social mobility.

As analysed above, before the divorce, these mothers' husbands were not sharing the caregiving work; on the contrary, some of these mothers were abused by their husbands both economically and physically. Facing life’s frustrations and the need to get by or even get ahead in life, they nevertheless were able to turn their motherhood identity, their beliefs in fate or religion, their high tolerance, their use of rational defence mechanisms, or their self-justification into sources of strength and motivation.

It is fate... if you do not keep going on in your current life, you will still need to do it in the next life. This is 'the cycle of reincarnation'... He is my child, I do my duty... now I practice Buddhism. $(\mathrm{Fu})$

I tried to kill myself twice... Now I go to the temple... Now I am busy and I feel happy. (Kou) I owe him (son with ID) to my last life; I return it back to him this generation. No choice, you must resign yourself to fate. (Ku)

Rolling with the punches. You meet it and you face it bravely. Accept fate. I gave birth to Wun (son with ID), I need to take care of Wun until I cannot do so... Be satisfied with life and feel good.

(Ping)

Guanxi with their family or social network was weak, and thus their informal as 
well as formal care capital was at a very low level. Nevertheless, these disadvantaged women were able to continue working at the same time as meeting their extensive care responsibilities. How was it possible? Where did the resources come from that made reconciliation between work and care attainable for them? In addition to Guanxi with their employers, religion and faith in fate as well as close relationships with their children with ID became sources of strength and motivation for this group of mothers not to kill themselves and to get by in their lives.

\section{Discussion}

Previous studies have indicated that the solution to the conflict between care and work faced by working lone mothers is to use various support systems, including childcare (Parker 1994, Lambert 1999, Stoloff et al. 1999, Mason 2003, Spencer-Dawe 2005, Millar \& Ridge 2008). This study is the first in Taiwan to listen to working lone mothers who have an adult child with ID and who have managed to combine care and work already for many years. These women were usually not entitled to formal support, either in cash or in kind. If they had access to any formal services, they needed to pay their costs either fully or partly. Consistent with previous studies (Corcoran et al. 2000, Danziger et al. 2000), we found that the lone mothers in our study lacked social capital and faced various major barriers in obtaining employment and in dealing with financial problems.

American studies (Corcoran et al. 2000, Scott et al. 2003) have found that low-income women rely heavily on informal childcare support in order to maintain their employment and are more likely to be unemployed due to a lack of childcare. The mothers in our study had faced a long-term struggle to balance the financial needs of their family and the lifelong care needs of their child with ID. Some of the mothers 
had even been abused by former husbands and had thought about committing suicide. In order to get by, the mothers worked in precarious low-paid jobs and built up good relationships and personal networks, Guanxi, with their employers. When their other children without disabilities grew up, they became significant resources within the mothers' informal networks; the mothers then felt their lives were becoming more settled and that they might even be getting ahead. However, this care capital could again be lost when these children moved out.

All in all, the availability of both formal and informal support to them was very limited; it had either never existed or had been lost due to the long duration of the special care needs of their child with ID. Having a low level of social capital and not receiving welfare state support, these lone mothers lacked care capital and were in care poverty (Kröger 2003, 2010).

Many Chinese people believe in fate and use it as a coping strategy. Our findings are consistent with Cheng and Tang's (1995) study, which found that in Chinese families who have a member with ID, the family's beliefs cannot be ignored. For most mothers in our study, their religious beliefs, belief in fate and motherhood identity were all tied to their child with ID. These women's motherhood identity, built over years from having a child with ID, can thus be seen as an important part of their unique individual care capital. Thus, individual religiousness, a belief in fate, and a strong motherhood identity can help these lone mothers to survive.

Furthermore, we found that combining care and work was not an issue of choice among these lone mothers. Lewis et al. (2000) noticed that non-employed mothers had a stronger motherhood identity compared with employed mothers. The lone mothers in this study, although they had paid work, still had a strong motherhood identity and this was not based on rational choice or 'preference theory' (Hakim 2000). This implies that taking up paid work or using social capital is a far more complex 
proposition than what has been suggested by previous theories.

\section{Conclusion}

By applying the concept 'care capital', this article has analysed how working lone mothers of adult children with ID have (or have not) obtained, lost, regained and lost again social capital during the life cycle. In general, this group of working mothers faced care poverty due to lack of formal and informal support, resulting from long-term care needs of their children and negative social attitudes towards people with ID. Building functional relationship with employers, religious beliefs and mother-child relationships proved to be the sole sources of care capital that supported these mothers to survive, to get by and sometimes, in the long run, even to get ahead in their lives.

Social and labour policies have not been especially useful for these disadvantaged women and in this respect there is plenty of room for improvement. Policies and services should be developed already at an early stage when the child with ID is still young and extended to his/her adulthood. Both the mother's and the child's life cycles need to be taken into account and included in the design of support programs. And finally, not only care services but also workplaces and working hours need to be designed and developed to fit with the mothers’ specific caregiving responsibilities.

\section{Limitations}

The sample of lone mothers of this study was relatively small and included only those who were involved voluntarily. Such convenience sampling cannot generate a 
representative sample of the whole population of working lone mothers of adult children with ID in Taiwan. How prevailing care poverty, care capital from employers and a new type of individual care capital (based on religion and mother-child relationship) are overall among lone mothers need to be confirmed with larger samples gathered from several areas and societies. It would also be worthwhile to compare, nationally and internationally, the level of lone mothers' care capital to that of working lone fathers with a disabled child and to that of working lone mothers with a child without disabilities. Despite the above-mentioned limitations, this study has aimed to contribute to efforts to better understand the linkages between the concepts of social capital, care capital and Guanxi among disadvantaged women who reconcile work and care, not just in Taiwan but globally.

\section{References}

Aryee S., Luk V., Leung A. \& Lo S. (1999) Role stressors, interrole conflict, and well-being: The moderating influence of spousal support and coping behaviors among employed parents in Hong Kong. Journal of Vocational Behavior 54, 259-278.

Backett-Milburn K., Cunningham-Burely S. \& Kramer D. (2001) Caring and proving: Lone and partnered working mothers in Scotland. Family Policy Studies Centre, London.

Beaujot R. \& Liu J. (2005) Models of time use in paid and unpaid work. Journal of 
Family Issues 26, 924-946.

Biernat M. \& Wortman C. B. (1991) Sharing of home responsibilities between professionally employed women and their husbands. Journal of Personality and Social Psychology 60, 844-860.

Bowen G. L. \& Orthner D. K. (1986) Single parents in the U.S. air force. Family Relations 35, 45-52.

Briggs X. D. (1998) Brown kids in while suburbs: Housing mobility and the many faces of social capital. Housing Policy Debate 9, 177-221.

Brisson D. (2009) Testing the relationship of formal bonding, informal bonding, and formal bridging social capital on key outcomes for families in low-income neighborhoods. Journal of Sociology \& Social Welfare 34, 167-183.

Brisson D. \& Usher C. L. (2007) The effects of informal neighborhood bonding social capital and neighborhood context on homeownership for families living in poverty. Journal of Urban Affairs 29, 65-75.

Burden D. S. (1986) Single parents and the work setting: The impact of multiple job and home life responsibilities. Family Relations 35, 37-43.

Burt R. S. (1987) Social contagion and innovation: Cohesion versus structural equivalence. American Journal of Sociology 92, 1287-1335.

Casey J. C. \& Pitt-Catsouphes M. (1994) Employed single mothers: Balancing job and home life. Employee Assistance Quarterly 9, 37-53.

Chan D. K.-S., Ng T. T.-T. \& Hui C.-M. (2010) Interpersonal relationships in rapidly changing Chinese societies. In M. H. Bond (Ed.) The Oxford handbook of Chinese psychology, pp.515-532. Oxford University Press, Oxford.

Chang C. F. , Sheu C. T. \& Chou Y. C. (1995) Living condition and coping strategies among single parent families. Unpublished study report. Taipei, Taiwan: Department of Research and Development, Executive Yuen, Taiwan. [in 
Chinese]

Chang Y. C. \& Pong S. H. (1996) Single parent families: The strength perspective. Soochow Journal of Social Work 2, 227-271. [in Chinese]

Chang P. Y. (1999) Fatherhood and parental-child relationship of divorce single father. Unpublished master thesis, Taipei, Taiwan: Graduate School of Children Welfare, Cultural University. [in Chinese]

Chen L. C. (2000) Relative mutual help and social assistance review: Female single parent family as an example. Sociology Journal of Chenchu University 30, 113-143. [in Chinese]

Cheng P. \& Tang C. S. (1995) Coping and psychological distress of Chinese parents of children with Down's syndrome. Mental Retardation 33, 10-20.

Chou Y. C. \& Palley H. A. (1998) The impact of having a child with developmental disabilities on the family in Taiwan: Cultural context review. Social Development Issues 20, 35-52.

Chou Y. C., Lee Y. C., Lin L. C., Chang A. L. \& Huang W. Y. (2008) Social services utilization by adults with intellectual disabilities and their families. Social Science \& Medicine 66, 2474-2485.

Chou Y. C., Pu C. Y., Lee Y. C., Lin L. C. \& Kröger T. (2009) Effect of perceived stigmatization on the quality of life among ageing female family carers: A comparison of carers of adults with intellectual disability and carers of adults with mental illness. Journal of Intellectual Disability Research 53, 654-664.

Chou Y. C., Pu C. Y., Kröger T. \& Fu L. Y. (2010) Caring, employment and quality of life: A comparison of employed and non-employed mothers of adults with ID. American Journal on Intellectual and Developmental Disabilities 115, 406-420.

Chou Y. C., Fu L. Y. \& Chang H. H. (2013) Making work fit care: reconciliation strategies used by working mothers of adults with intellectual disabilities. 
Journal of Applied Research in Intellectual Disability 26, 133-145.

Ciabattari T. (2007) Single mothers, social capital, and work-family conflict. Journal of Family Issues 28, 34-60.

Coleman J. S. (1988) Social capital in the creation of creation of human capital. American Journal of Sociology 94, 95-120.

Coleman J. C. (1994) Foundations of Social Theory. Harvard University Press, Cambridge, Mass.

Corcoran M., Danziger S. K., Kalil A. \& Seefeldt K. S. (2000) How welfare reform is affecting women’s work. Annual Review of Sociology 26, 241-269.

Crouter A. C. (1984) Spillover from Family to Work: the Neglected Side of the Work-family Interface. Human Relations 37, 425-442.

Danziger S. K., Kalil A. \& Anderson N. J. (2000) Human capital, health and mental health of welfare recipients: Co-occurrence and correlates. Journal of Social Issues 56, 635-654.

Derose K. P. (2008) Do bonding, bridging, and linking social capital affect preventable hospitalizations? Health Services Research 43, 1520-1541.

Dominguez S. \& Watkins C. (2003) Creating networks for survival and mobility: Social capital among African-American and Latin-American low-income mothers. Social Problems 50, 111-135.

Duncan S. \& Edwards R. (1999) Lone mothers, paid work and gendered moral rationalities. Macmillan, Basingstoke.

Feng J. Y. \& Han W-J. (2010) Maternity leave in Taiwan. Family Relations 59, 297-312.

Gold T., Guthrie D. \& Wank D. (2002) An introduction to the study of Guanxi. In T. 
Gold (Ed.) Social connections in China: institutions, culture, and the changing nature of Guanxi, pp. 3-20, Cambridge University Press, West Nyack, NY, USA.

Gordon M., Rosenman L. \& Cuskelly M. (2007) Constrained labour: maternal employment when children have disabilities. Journal of Applied Research in Intellectual Disabilities 20, 236-246.

Hakim C. (2000) Work-lifestyle choices in the 21st century, preference theory. Oxford University Press, Oxford.

Halford S., Savage M. \& Witz A. (1997) Gender, careers and organisations. Macmillan, London.

Hao L. \& Brinton M. C. (1997) Productive activities and support systems of single mothers. American Journal of Sociology 102, 1305-1344.

Harris K. M. (1993) Work and welfare among single mothers in poverty. American Journal of Sociology 99, 317-352.

Kamerman S. B. \& Kahn A. J. (1988) Mothers alone: Strategies for a time of change. Auburn House, Dover, MA.

Kröger T. (2003) Pohdintoja sosiaalisen pääoman ympärillä [Reflections around social capital]. Unpublished work paper, 6 March 2003, University of Tampere.

Kröger T. (2010) Lone mothers and the puzzles of daily life: Do care regimes really matter? International Journal of Social Welfare 19, 390-401.

Lambert S. J. (1999) Lower-wage workers and the new realities of work and family. Annals of the American Academy of Political and Social Science 562, 148-158.

Leira A., Tobio C. \& Trifiletti R. (2005) Kinship and informal support: Care resources for the first generation of working mothers in Norway, Italy and Spain. In U. Gerhard, T. Knijn \& A. Weckwert (Eds.) Working mothers in 
Europe: A comparison of policies and practices, pp.74-96. Edward Elgar, Cheltenham, UK.

Leonard B., Brust J. D. \& Sapienza J. J. (1992) Financial and time costs to parents of severely disabled children. Public Health Reports 107, 302-312.

Lewis S., Kagan C. \& Heaton P. (2000) Dual-earner parents with disabled children: Family patterns for working and caring. Journal of Family Issues 21, 1031-1060.

Lin L. C. \& Cheng L. C. (2001) Strategies for coping family and work role among divorced fathers. Social Policy \& Social Work 5, 113-174. [in Chinese]

Lin N. (2001) Social capital: A theory of social structure and action. Cambridge University Press, Cambridge.

Lowndes V. (2004) Getting on or getting by? Women, social capital and political participation. British Journal of Politics and International Relations 6, 47-56.

Lu L., Gilmour R., Kao S. F. \& Huang M. T. (2006) A cross-cultural study of work/family demands, work/family conflict and wellbeing: the Taiwanese vs British. Career Development International 11, 9-27.

Mason R. (2003) Listening to lone mothers: Paid work, family life, and childcare in Canada. Journal of Children \& Poverty 9, 41-54.

Millar J. \& Ridge T. (2008) Relationships of care: Working lone mothers, their children and employment sustainability. Journal of Social Policy 38, 103-121.

MOI (Ministry of Interior), Taiwan (2009) Statistical data for people with disabilities. available online at http://www.moi.gov.tw/ (last accessed 20 January, 2013) [In Chinese] 
Nelson M. K. (2000) Single mothers and social support: The commitment to, and retreat from, reciprocity. Qualitative Sociology 23, 291-317.

Parker L. (1994) The role of workplace support in facilitating self-sufficiency among single mothers on welfare. Family Relations 43, 168-173.

Pong S. H. (2005) Conjugal families? Birth families? Where is my home? The family support system among female single parents. Social Policy \& Social Work 9, 197-262. [in Chinese]

Porterfield S. L. (2002) Work Choices of Mothers in Families with Children with Disabilities. Journal of Marriage and Family 64, 972-981.

Putnam R. D. (2000) Bowling alone: The collapse and revival of American community. Simon \& Schuster, New York.

Putnam R. D. (2002) Democracies in flux: The evaluation of social capital in contemporary society. Oxford University Press, Oxford.

Scott E., Hurst A. \& London A. S. (2003) Out of their hands: Patching together care for children when parents move from welfare to work. The Next Generation, Working Paper Series, No. 16, available online at http://www.mdrc.org/publications/370/full.pdf (last accessed 1 April 1 2011)

Skevik A. (2005) Women's citizenship in the time of activation: The case of lone mothers in "needs-based” welfare state. Social Politics: International Studies in Gender State and Society 12, 42-66.

Smith J. A., Flowers P. \& Larkin M. (2009) Interpretative phenomenological analysis: Theory, method and research. SAGE, London.

Spector P. E., Allen T. D., Lapierre L. M., Poelmans S., Cooper C. L., O’Driscoll M. P., et al. (2007) Cross-national differences in relationships of work demands, job satisfaction and turnover intentions with work-family conflict. Personnel Psychology 60, 805-835. 
Spencer-Dawe E. (2005) Lone mothers in employment: Seeking rational solutions to role strain. Journal of Social Welfare and Family Law 27, 251-264.

Stoloff J. A., Glanville J. L. \& Bienenstock E. J. (1999) Women’s participation in the labor force: The role of social networks. Social Networks 21, 91-108.

Tang C. S.-k., Chua Z. \& O J. (2010) A gender perspective on Chinese social relationships and behavior. In M. H. Bond (Ed.) The Oxford handbook of Chinese psychology, pp.533-554. Oxford University Press, Oxford.

Traustadottir R. (1991) Mothers who care: Gender, disability, and family life. Journal of Family Issues 12, 211-228.

Wellman B. \& Gulia M. (1999) The network basis of social support: A network is more than the sum of its ties. In B. Wellman (Ed.) Networks in the global village: Life in contemporary communities, pp.83-118. Westview, Boulder, CO.

Wu W. H. (2000) Relationships between three generations: Parental and intergeneration support to divorced daughters and their children. Unpublished master thesis. Taipei, Taiwan: Graduate School of Sociology, National Taiwan University.

Xin K. \& Pearce J. (1996) Guanxi: connections as substitutes for formal institutional support. Academy of Management Journal 39, 1641-1658. 
Table 1 Characteristics of the participants

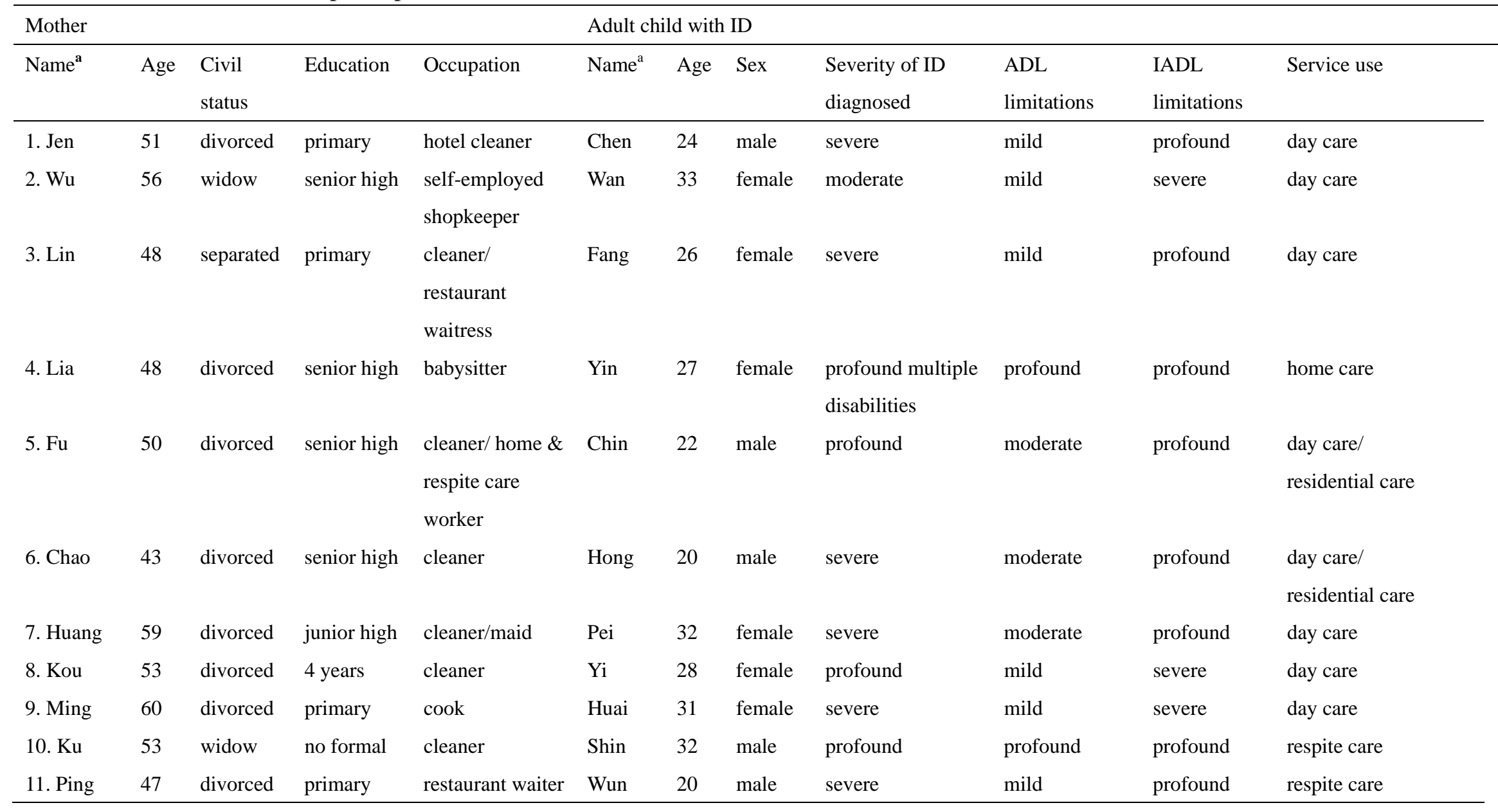

a Pseudonyms. 
Table 2 Main themes and sub-themes from the analysis of the interviews on work-care reconciliation of lone mothers of adult children with ID

Main theme A. Extremely limited care capital: lost, gained and lost again

Sub-theme 1. Fathers as no source of care capital (before or after divorce)

Sub-theme 2. Care capital from parents (and ex-parents-in-law) and siblings lost or never existed

Sub-theme 3. Care capital from other children gained and lost again

Sub-theme 4. No care capital arising from personal and formal networks

Main theme B. Guanxi with employers: the sole source of care capital

Sub-theme 1. Kin employers

Sub-theme 2. From formal to informal relationships

Sub-theme 3. Fluid boundaries between the workplace and caregiving

Sub-theme 4. Reciprocal relationships

Main theme C. Religion and mother-child relationships: a new type of care capital 